\title{
FinTech and Green Finance: The Case of Ant Forest in China
}

\author{
Jiaheng Zhang \\ ${ }^{1}$ DongWu Business School, Soochow University, Suzhou, Jiangsu Province, 215021, China \\ *Corresponding author. Email: 1252914398@qq.com
}

\begin{abstract}
In the process of green economic development in China, commercial banks have been playing a leading role. With the development of FinTech and its extensive use in the financial area, green finance has developed new innovative models such as Ant Forest based on the Internet, big data, and mobile payment system. To examine the use of FinTech in green finance, a qualitative case study research method is adopted using secondary data. Through case analysis and comprehensive analysis of the public welfare practice of green finance represented by Ant Forest, this paper aims to propose the possibility of developing green finance with financial technology through launching innovative popular green financial products. Overall, the research shows that the technological innovation financial product (Ant Forest) based on big data and mobile payment has a great effect on reducing carbon emissions and improving environmental problems, thereby promoting the development of green finance. The study contributes to the "FinTech + Green Finance" model and highlights its effectiveness in the development of green finance during the era of scientific and technological innovation.
\end{abstract}

Keywords: FinTech, Green Finance, Ant Forest, Carbon emission

\section{INTRODUCTION}

As environmental problems become increasingly serious, the balance between economic development and environmental protection is constantly broken. The advocacy of environmental protection continues to develop, and the academic circle continues to deepen the research on green finance. Cowan identified green finance as a discipline including environmental economics and finance, and put forward various suggestions on financing for the development of the environmental economy[1]. Starting from the relationship between banking industry and environmental economy, Jeucken discovered the mechanism of using financial means to encourage economic subjects to actively participate in environmental protection[2]. Recent studies find that green finance plays a role in improving environmental quality by implementing environmentally-related regulations and minimizing carbon dioxide (CO2) emissions[3][4][5]. Although the scope of green finance research is expanding to include many aspects and fields, few scholars have examined its effects on environmental improvement by reducing carbon emissions against the backdrop of FinTech development. This paper combines FinTech with green finance by taking Alipay's Ant Forest as an example to explore new ideas for the development of green finance. Therefore, the question arises as to whether green finance can make full use of FinTech to create green financing models that are different from traditional ones, broaden financing channels and enhance incentive mechanisms. To examine the use of FinTech in green finance, a qualitative case analysis research methodology is adopted using secondary data. This paper aims to contribute to providing a possible solution to the current problems of green finance in China such as financing difficulties and lack of internal incentives, so as to promote the further development of China's green finance.

The remaining work is organized in the following sections. After this introduction, Section 2 describes literature reviews on FinTech and green finance. Section 3 illustrates a case study to support the research topic. Section 4 provides the conclusion part of the study.

\section{LITERATURE REVIEW}

\subsection{Financial Technology (FinTech)}

FinTech is the abbreviation for Financial Technology, which is aimed to deliver financial services and products 
for its consumers in user-friendly and convenient ways using technology innovatively[6]. Fintech is an emerging concept, which is widely used in payment, blockchain, investment, lending, data analytics, environmental protection and many other fields. Some of the FinTech phenomena have been well-studied in the environmental sustainability area including agriculture sustainability[7] and small-scale renewable energy[8] and Information Systems (IS) area such as mobile payment[9] and peerto-peer (P2P) lending[10].

\subsection{Green Finance}

Green finance has yet to develop a clear definition. In academic circles, researchers have not yet reached a consensus on the concept of green finance[11]. According to The G20 Green Finance Study Group, green finance is defined as "Financing of investments that provide environmental benefits in the broader context of environmentally sustainable development." [12] As a new type of financial instrument, green finance is put forward to solve environmental problems. It serves as a bridge between environmentally friendly behavior and the financial and business world[13], encouraging investment in new technologies and innovations.
Our literature review shows that few studies have combined FinTech with green finance in the form of a mobile payment system. The findings of such studies provide an alternative approach to develop green finance through FinTech. Therefore, this study aims to fill this gap by carrying out a theoretical analysis on the application of FinTech to promote green finance and sustainable development through an in-depth case study.

\section{CASE ANALYSIS}

Ant Forest is an eco-friendly product launched by Alipay's carbon account, which is mainly used to measure the carbon emission reduction in people's daily activities such as walking, biking, taking the subway and online payment of utility bills. The amount of carbon emission reduced through these low-carbon behaviors can be translated into virtual energy (green energy) accumulated to raise a virtual tree in the carbon account. Green energy not only records the carbon footprint, but also forms a trading account for carbon assets. When the energy accumulates to a certain amount, a real tree will be planted by non-profit organizations and environmental protection enterprises.

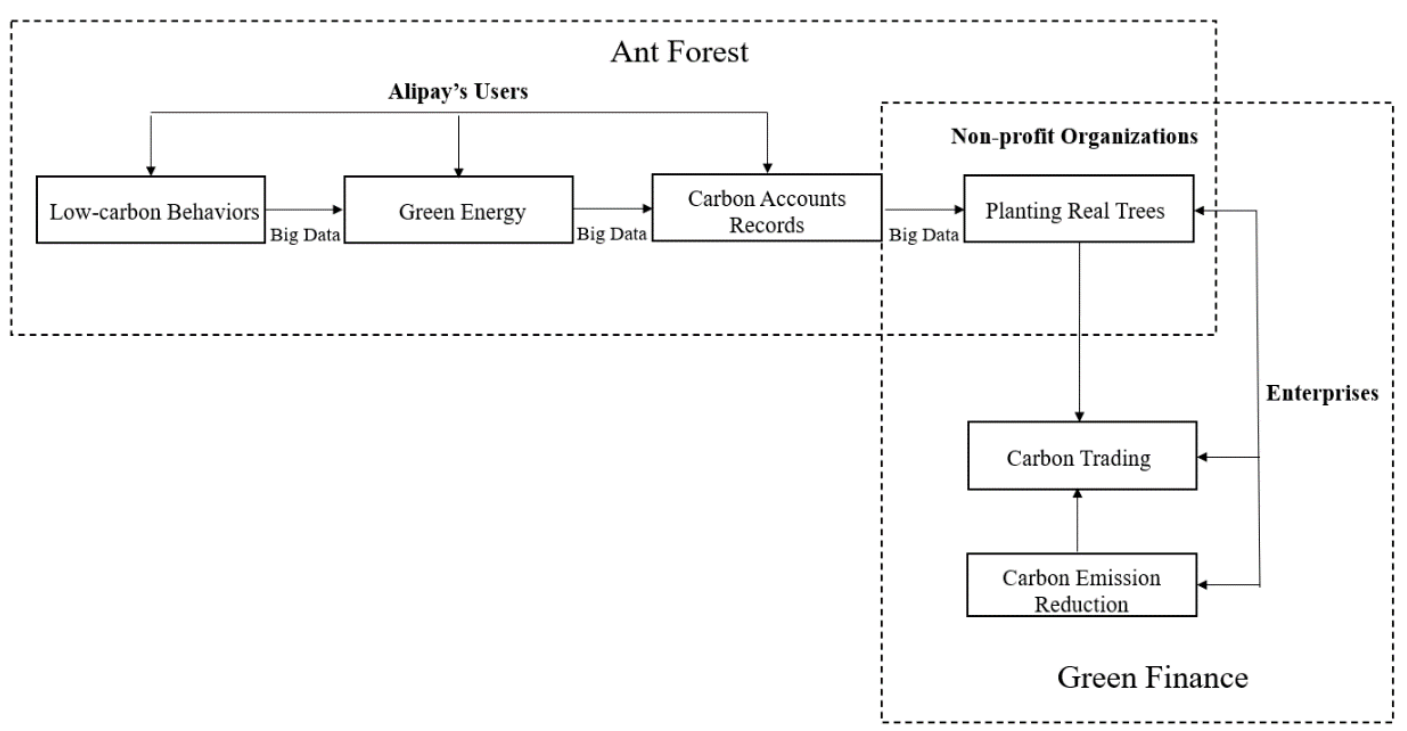

Figure 1 The operation mode of Ant Forest combining FinTech and green finance

The flowchart above is an operation mode of Ant Forest combining FinTech and green finance. This part will discuss the model from three aspects: Ant Forest and Green Finance, Ant Forest and FinTech, and FinTech and Green Finance.

\subsection{Ant Forest and Green Finance}

Green finance is defined as "Financing of investments that provide environmental benefits in the broader context of environmentally sustainable development. These environmental benefits include, for example, reductions in air, water and land pollution, reductions in greenhouse gas (GHG) emissions, improved energy efficiency while utilizing existing natural resources, as well as mitigation of and adaptation to climate change and their co-benefits." [12]

For a long time, the development of green finance in China has been mainly felling on enterprises in the form of green bonds and green credit, and the development form is relatively simple, resulting in the low participation of ordinary consumers in green finance. However, Alipay's carbon account allows ordinary users to participate with a lower entry threshold. 
The Ant Forest platform created by "Internet + Finance" is a typical case of green finance. As a new type of green financial development mode, the Ant Forest uses Internet technology to combine business directly with individual users, makes public benefit activities with low active users into entertaining games, and transforms traditional ways of endowment into low-cost and "Internet + Green Finance" form of public welfare project, making effective use of a market economic mechanism to develop forestry and promoting economic transformation and upgrading towards green and sustainable development. Ant Forest makes the relationship between green finance and individuals closer, so as to pool individual power to help the development of green finance.

An important way to implement green finance is the establishment and operation of a carbon trading market. Carbon trading is a new market mechanism used to reduce global greenhouse gas and carbon dioxide emissions. It is essentially a financial activity[14]. On the one hand, financial capital can be introduced to invest directly or indirectly in projects and enterprises that create carbon assets. On the other hand, the emissions reductions generated by these different projects and companies could be traded in carbon markets and developed into standard financial instruments. As a new way of reducing carbon emission, carbon trading can realize the effective allocation of greenhouse gas emission in a low-cost and high-efficiency way and achieve the implementation goal of rational utilization of public resources.

With the help of the carbon trading market, lowemission enterprises can directly trade in their energysaving and emission reduction achievements, thus realizing market-oriented incentives for environmental protection behaviors. Using the means of green finance can effectively support environmental protection public welfare projects. Over the past five years, Ant Forest has attracted more than 600 million users, reduced carbon emissions by 20 million tons, planted 326 million trees in 11 provinces and set up 18 public protection sites in 10 provinces[15]. If these emission reductions could be included in the carbon trading system, they would be worth hundreds of millions of yuan at current market prices. This is a huge boost to both public welfare projects and the income level of farmers and herdsmen. In addition to providing direct financial support for environmental protection projects, green finance realizes the purchase, sale and investment of carbon assets in public welfare projects through the carbon account of environmental protection projects when conditions are ripe.

The involvement of green finance can not only improve the economic returns of environmental public welfare projects, but also attract commercial investment in the projects, thus promoting the long-term sustainable development of environmental public welfare activities.

\subsection{Ant Forest and FinTech}

FinTech is defined as new products, applications, and business models provided through the use of innovative technology in the financial area that could have a huge impact on the development of the financial services and financial industry, creating a competitive market environment among service providers[16]. Based on a series of technological innovations such as big data, cloud computing, artificial intelligence and blockchain, FinTech is comprehensively applied to six financial sectors, including payment and clearing, lending and financing, wealth management, retail banking, insurance and transaction settlement. It is the mainstream trend of the financial industry in the future.

According to the UNDP report, Ant Forest provides solutions to environmental problems with technological innovation based on "digital finance" and exports Chinese samples to the world, demonstrating China's strength in environmental protection and public welfare[17].

Traditional public welfare organizations have disadvantages such as inadequate technology and supervision. However, the emergence of the Internet has given the public welfare more transparent supervision, more advanced technology and more influential advantages, allowing the Internet public welfare model to undergo a thorough reform. As the head of the Internet sector, Alibaba has a high degree of public trust. Ant Forest uses the influence of Alibaba platform as a link to connect the public, users, enterprises and other organizations, improving the traditional model of public welfare and expanding the influence of public welfare.

Ant Forest automates the production of green energy. The core use path of the entire product is very short, and it can directly reach the core function at the fastest speed to complete the functional closed loop. Through visualization and observable effects, the results of Ant Forest can be monitored and observed step by step by the user. Through virtual simulation technology such as the image of real trees and virtual animation, users can check the situation of their trees at any time in the process of transforming virtual trees into real trees. This engagement can improve the user experience, save time and energy, lower the threshold of public welfare environmental protection, and improve the user-platform efficiency. It is the special system of Ant Forest that connects the online and offline scenes that makes it possible for everyone to participate in green finance.

Ant Forest has 600 million users and its operation mode relies on big data finance, mainly basing on the widespread use of Alipay to collect a large amount of relevant data and set up personal carbon accounts. Big 
data computing provides technical support and guarantees for online public welfare, enabling users to obtain personalized services that conform to their own habits after big data analysis and calculation and then complete online public welfare activities. In addition, the Ant Forest uses Internet platform to start commercial operation, relies on Alibaba Group's capital and human support, and gathers all kinds of super APP platform entrance, thereby combining public welfare activities with all kinds of businesses, institutions and users effectively, reducing the threshold of user experience in public welfare, and encouraging users to adhere to the greenway of life to a deeper extent.

\subsection{FinTech and Green Finance}

Through the use of big data analysis and artificial intelligence, FinTech plays a vital role in providing green finance to make a green transition among consumers and small and medium-sized enterprises (SMEs)[18]. Ant Forest is the innovative business model involving FinTech in environmental protection efforts in China. It shows how FinTech platforms work to effectively motivate Alipay's users to participate in the green finance projects by encouraging them to reduce their carbon footprint. Green financing, along with technological innovation, is expected to contribute to successful environmental protection initiatives.

At present, China has entered a special period of adjusting economic structure and transforming economic development mode, and there is an increasing demand for green finance development. However, as green finance is in the initial stage of its development, there are inevitably some bottlenecks such as a huge financing gap and lack of internal motivation. More and more investors with innovative financial thinking are expected to enter the investment circle of green finance to create more "Ant Forests" or even promote green financial trade between countries, so as to strive to promote the development of green finance in China and strive for the construction of a mature green financial market.

Green finance projects now mainly focus on green credit, green bonds and green development funds for large enterprises and projects, which is the current situation around the world. The green finance market has great potential, but innovation is lacking. The new form of "FinTech + Green Finance" makes it possible to further develop the green finance market.

\section{CONCLUSION}

Green finance is an evolving global trend, and it is becoming more and more important for nations to achieve sustainable development. In the context of the new round of industrial revolution and technological revolution, financial technology is booming using technology-driven financial innovation to subvert the development of the traditional financial industry. As an innovative mode of green finance in China, Ant Forest reflects a new development path of green finance different from the traditional green finance mode under the background of the era of FinTech, which is conducive to the further development of green finance. There are also some shortcomings in our current study. Limited data availability meant the effects of FinTech on the green finance could not be exhaustively studied. The single case limited our ability to put forward a more precise model of how to combine FinTech with green finance. Basing on our findings, future research can focus on the building of a more accurate model of the application of FinTech in green finance.

\section{REFERENCES}

[1] Cowan, E. (1998). Economy and Environment Program for Southeast Asia (EEPSEA). Topical Issues in Environmental Finance.

[2] Jeucken, M. (2006). USA: The Earthscan Publication. Sustainable Finance and Banking.

[3] Nouira, I., Hammami, R., Frein, Y., \& Temponi, C. (2016). Design of forward supply chains: Impact of a carbon emissions-sensitive demand. International Journal of Production Economics, 173, 80-98.

[4] Li, L., Liu, D., Hou, J., Xu, D., \& Chao, W. (2019). The study of the impact of carbon finance effect on carbon emissions in Beijing-Tianjin-hebei region based on logarithmic mean divisia index decomposition analysis. Sustainability, 11(5), 1465.

[5] Brandi, C., Schwab, J., Berger, A., \& Morin, J.-F. (2020). Do environmental provisions in trade agreements make exports from developing countries greener? World Development, 129, 104899.

[6] Dorfleitner, G., Hornuf, L., Schmitt, M., \& Weber, M. (2017). FinTech in Germany. Springer International Publishing.

[7] Muhammad, A., Mohammad N. A., Masairol M., \& Mahani H. (2019). Digital Marketplace and FinTech to Support Agriculture Sustainability. Energy Procedia, 156, 234-238.

[8] Hemen, M. B., Benyoh, E. K. N., Sang W. P., \& Jeung, S. H. (2021). Leveraging community based organizations and fintech to improve small-scale renewable energy financing in sub-Saharan Africa. Energy Research \& Social Science, 73, 101949.

[9] Ahmad, D., Csaba, L., \& Judit, S. (2021). FinTech payments in the era of COVID-19: Factors influencing behavioral intentions of "Generation $\mathrm{X}$ " in Hungary to use mobile payment. Journal of Behavioral and Experimental Finance, 32, 100574. 
[10] Kaleemullah, A., Ashraful, A., Noor, A. B., Imtiaz, A. B., \& Shahzad, N. (2021). P2P lending Fintechs and SMEs' access to finance. Economics Letters, 204, 109890.

[11] Zhang, D., Zhang, Z., \& Managi, S. (2019). A bibliometric analysis on green finance: Current status, development, and future directions. Finance Research Letters, 29, 425-430.

[12] Group, G. F. S. (2016). G20 green finance synthesis report.

[13] Scholtens, B. (2017). Why finance should care about ecology. Trends in Ecology \& Evolution, 32(7), 500-505.

[14] He, S. Y. (2019). The beginning of green finance: Analysis through the perspective of "Ant Forest". China Circulation Economy, (19), 145-146.

[15] Li, B. (2021). Bringing 600 million people to "reduce carbon" in 5 years: Ant Forest and 100 companies start the "Green Energy Action".

https://baijiahao.baidu.com/s?id=17090607685487 $03590 \& w f r=$ spider $\&$ for $=$ pc

[16] Thakor, A.V. (2020). Fintech and banking: What do we know? J. Financ. Intermed. 41, 100833.

[17] Yang, Y. (2017). Ant Forest has more than 200 million users, UN Carbon Report says it is unique https://www.sohu.com/a/126531881_162758

[18] Duchene, S. (2020). Review of handbook of green finance. Ecological Economics, 177, 106766. 